\title{
SISTEM INFORMASI GEOGRAFIS GARDU LISTRIK PT. PLN (Persero) APJ MAJALAYA
}

\author{
Aditya Galih Sulaksono \\ Fakultas Teknologi Informasi, Universitas Merdeka Malang \\ Email : adit@unmer.ac.id
}

\begin{abstract}
Geographic Information System is a system information that aims to present information in depreciation and includes objects - objects the ADA on the surface of the earth and DI hearts. Different advantages offered by depreciation and information system, including the presentation of Adjusted with the user requirements system, with statistical analysis using different visualization The Typical And Able advantages offered through the analysis of depreciation and drawings through the map / floor plan. Design of information systems depreciation and combine raw data company between the map data can be simplify decision hearts put substation electrical installation nearby.
\end{abstract}

\section{Keywords : geographic information systems, decision support systems, electrical substations}

\section{PENDAHULUAN}

Listrik merupakan salah satu komponen penting dalam kehidupan manusia. Keberadaannya pun sudah menjadi kebutuhan pokok dalam kehidupan sehari-hari, karena segala sesuatunya kini sudah menggunakan energi listrik. Mulai dari alat-alat rumah tangga hingga industri-industri besar membutuhkan energi listrik untuk melakukan aktifitas dalam pekerjaannya.

Tuntutan masyarakat akan penyediaan energi listrik ini pun semakin meningkat seiring dengan perkembangan jaman. PLN sebagai salah satu penyedia energi listrik di Indonesia berusaha untuk memenuhi permintaan masyarakat tersebut, yaitu dengan membangun gardu-gardu listrik di tiap-tiap daerah yang belum mendapatkan pasokan listrik. Pembangunan gardu-gardu listrik ini membutuhkan ketepatan dalam penempatan koordinat lokasinya. Hal ini dimaksudkan agar daya listrik yang terdapat pada gardu tersebut dapat disalurkan sesuai dengan jumlah daya listrik yang dibutuhkan di daerah tersebut.

Pentingnya validasi koordinat lokasi gardu listrik ini bertujuan untuk mempermudah PLN dalam pencarian lokasi gardu. Sehingga masalah yang timbul cepat dapat ditangani dengan segera dan memudahkan para petugas lapangan PLN dalam menanggulangi masalah yang timbul.

Sistem Informasi Geografis merupakan suatu sistem informasi yang bertujuan menyajikan informasi geografis yang meliputi objek-objek yang ada di permukaan dan di dalam bumi. Berbagai kelebihan ditawarkan oleh sistem informasi geografis, diantaranya penyajian yang disesuaikan dengan kebutuhan pengguna sistem, analisis statistik dengan menggunakan visualisasi yang khas serta berbagai keuntungan yang mampu ditawarkan melalui analisis geografis melalui gambar-gambar peta/denah.[1]

Kemampuan tersebut membuat sistem informasi geografis berbeda dengan sistem informasi pada umumnya dan membuatnya berharga bagi perusahaan untuk memberikan penjelasan tentang suatu peristiwa, membuat peramalan kejadian, dan perencanaan strategis lainnya.[1]

Dengan menggunakan sistem informasi geografis, informasi yang ada dapat diasosiasikan pada sebuah struktur informasi yang berbasis pemetaan secara geografis, sehingga sistem informasi geografis akan memberikan peran yang besar dalam membantu mengorganisasikan informasi-informasi yang diinginkan dan akan diperoleh lebih banyak lagi informasi yang didapatkan.

\section{Sistem Informasi Geografis}

Sistem adalah kumpulan dari elemen-elemen yang berinteraksi untuk mencapai suatu tujuan tertentu.

Informasi adalah data yang diolah menjadi bentuk yang lebih berguna dan berarti bagi yang menerimanya" 
Sistem Informasi Geografis (SIG) merupakan sistem infomasi berbasis komputer yang menggabungkan antara unsur peta (geografis) dan informasinya tentang peta tersebut (data atribut) yang dirancang untuk mendapatkan, mengolah, memanipulasi, menganalisa, memperagakan dan menampilkan data spasial (informasi bereferensi geografis).

Sistem Informasi Geografis dapat diuraikan menjadi beberapa subsistem berikut :

1. Data Input

Subsistem ini bertugas untuk mengumpulkan dan mempersiapkan data spasial dan atribut dari berbagai sumber.

2. Data Output

Subsistem ini menampilkan atau menghasilkan keluaran seluruh atau sebagian basis data baik dalam bentuk softcopy maupun bentuk hardcopy.

\section{Data Management}

Subsistem ini mengorganisasi baik data spasial maupun atribut kedalam sebuah basis data sedemikian rupa sehingga mudah dipanggil, di-update, dan di-edit.

4. Data Manipulation \& Analysis

Subsistem ini menentukan informasiinformasi yang dapat dihasilkan oleh SIG. Subsistem ini juga melakukan manipulasi dan pemodelan data untuk menghasilkan informasi yang diharapkan.

\section{Context Diagram}

Diagram konteks merupakan diagram yang mengandung satu proses yang menggambarkan hubungan keterkaitan antara sistem dengan pihak-pihak diluar lingkungan sistem dan posisi sistem didalam lingkungan tersebut. Pihak-pihak tersebut merupakan pihak-pihak yang membutuhkan informasi dan data dari sistem ataupun pihak-pihak yang menjadi sumber informasi dan data bagi sistem. Hubungan keterkaitannya digambarkan sebagai aliran informasi dan data yang masuk ke dalam sistem dan keluar dari sistem.

Dengan kata lain diagram konteks adalah sebuah diagram sederhana yang menggambarkan hubungan antara entitas luar, masukan dan keluaran dari sistem.

\section{METODE PENELITIAN}

Metodologi yang akan digunakan dalam proses pembuatan Sistem Informasi Geografis ini adalah sebagai berikut :
1. Tahap pengumpulan data

Metode pengumpulan data yang digunakan dalam pembuatan Sistem Informasi Geografis ini adalah sebagai berikut :

a. Studi Kepustakaan

Teknik pengumpulan data dengan mempelajari sumber-sumber pustaka yang berkaitan dengan Sistem Informasi Geografis yang akan dibangun.

b. Wawancara

Teknik pengumpulan data dengan cara mengadakan tanya jawab secara langsung kepada bagian Sistem Informasi PT. PLN (Persero) APJ Majalaya.

2. Tahap pembuatan perangkat lunak

Teknik analisis data dalam pembuatan Sistem Informasi Geografis ini menggunakan paradigma perangkat lunak secara waterfall, yang meliputi beberapa proses diantaranya :

\section{a. Rekayasa Sistem}

Tahap ini dimulai dengan menetapkan berbagai kebutuhan dari semua elemen yang diperlukan sistem dan mengalokasikannya kedalam pembentukan perangkat lunak

\section{b. Analisis}

Tahap ini merupakan tahap menganalisis hal-hal yang diperlukan dalam pelaksanaan pembuatan Sistem Informasi Geografis, seperti Analisis User, Analisis Data, Analisis Sistem

c. Desain

Tahap ini merupakan proses penerjemahan dari data yang telah dianalisis kedalam bentuk yang lebih mudah dimengerti

\section{d. Pengkodean}

Tahap penerjemahan data atau pemecahan masalah yang telah dirancang kedalam suatu bahasa pemrograman tertentu

e. Pengujian

Pada tahap ini akan dilakukan proses pengujian terhadap Sistem Informasi Geografis yang telah dibuat

f. Pemeliharaan

Merupakan tahap akhir dimana suatu perangkat lunak yang sudah selesai dapat mengalami perubahan-perubahan atau penambahan sesuai dengan permintaan user

\section{HASIL DAN PEMBAHASAN}

Untuk menggambarkan sistem informasi geografis garduu listrik secara keseluruhan dapat digambarkan pada diagram konteks seperti pada gambar 1. Dari gambar 1 
tersebut dapat dijelaskan beberapa proses yang ada, diantaranya adalah:

1. Proses Pendataan Awal

Pada proses ini dicatat dan disimpan semua data mentah yang ada di dalam perusahaan yang berhubungan dengan gardu listrik. Seperti data kecamatan, data pelanggan, data gardu, dan data peta yang menunjukkan letak gardu listrik tersebut berada.

\section{Proses Login}

Dengan adanya proses login, makan hanya user tertentu saja yang bisa mengakses kedalam system ini. Administrator akan mendapat hak akses secara penuh yang meliputi menambah data, menghapus data, dan merubah data untuk semua kebutuhan data yang mendukung sistem. Sedangkan staf hanya akan mendapat hak akses kedalam sistem seperti melihat data pelanggan, melihat data peta pelanggan, dan melihat beban gardu listrik.

\section{Proses Pengolahan Data}

Pengolahan data dilakukan oleh administrator yang mencakup data kecamatan, data desa, data pelanggan, dan data gardu.

4. Proses Pengolahan SIG

Untuk melakukan proses pengolahan SIG sebelumnya dilakukan proses digitasi terhadap peta yang dimaksud. Data peta yang dimasukkan adalah data peta kecamatan, data peta desa, dan data peta gardu. Setelah semua data terkumpul dan sudah dilakukan proses digitasi, kemudian dilakukan penggabungan data dari data mentah yang diperoleh dari perusahaan dengan data peta digital yang sudah jadi. Hal ini dimaksudkan untuk memudahkan pada proses pencarian nantinya.

\section{Proses Pencarian}

Proses pencarian dapat dilakukan oleh semua user, yaitu administrator dan staf. Proses pencarian ini semua data mentah dan data peta disatukan. Data-data tersebut antara lain yaitu data kecataman, data desa, data pelanggan, dan data gardu. User dapat memilih jenis pencarian yang dimaksud sesuai dengan data yang tersedia diatas. Setelah user memasukkan kata kunci pada kotak pencarian, maka akan dimunculkan detil dari hasil-hasil pencarian yang dimaksud.

\section{Proses Informasi Peta}

Pada proses ini akan ditampilkan data peta tentang layer kecamatan, layer desa, dan layer gardu. User dapat melihat informasi yang tersedia seperti jumlah gardu yang terdapat dalam suatu desa dan kecamatan, data beban listrik yang terdapat dalam satu gardu.

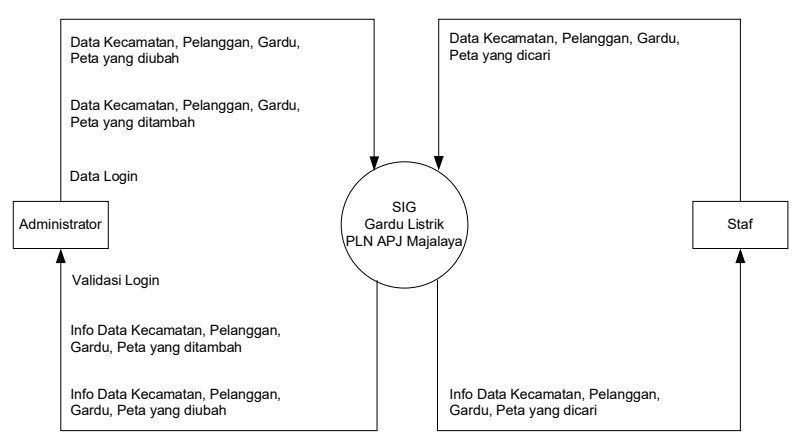

Gambar 1. Diagram konteks

\section{Detil-Detil Proses Pengolahan Data}

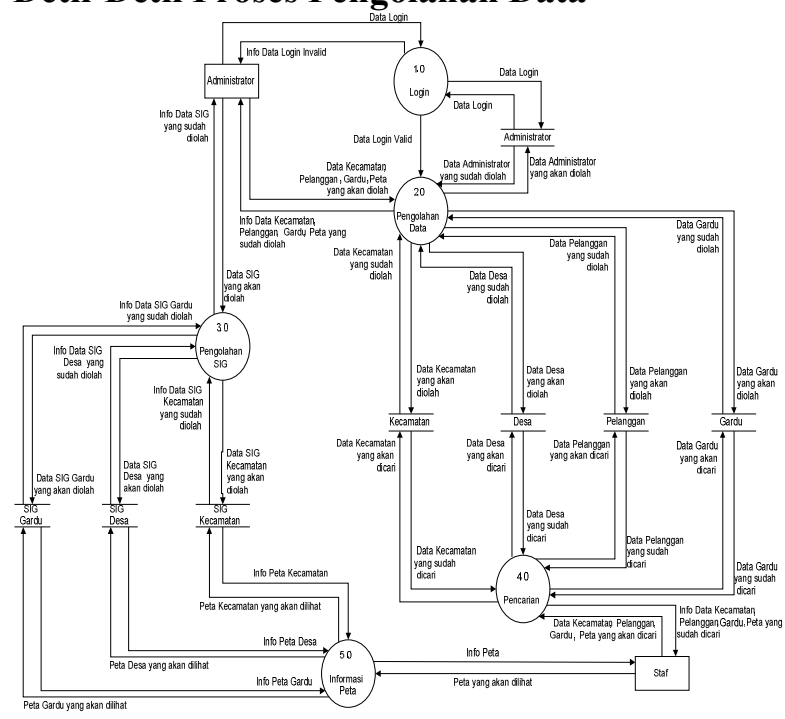

Gambar 2. Grafik Data Flow Diagram

Gambar di atas menjelaskan tentang pergerakan alur-alur data yang berjalan pada sistem baik yang dibaca maupun disimpan pada database.

\section{Struktur Basis Data}

Dalam pembuatan sistem informasi eografis ini diperlukan pembaruan basis data juga, diantaranya adalah: 


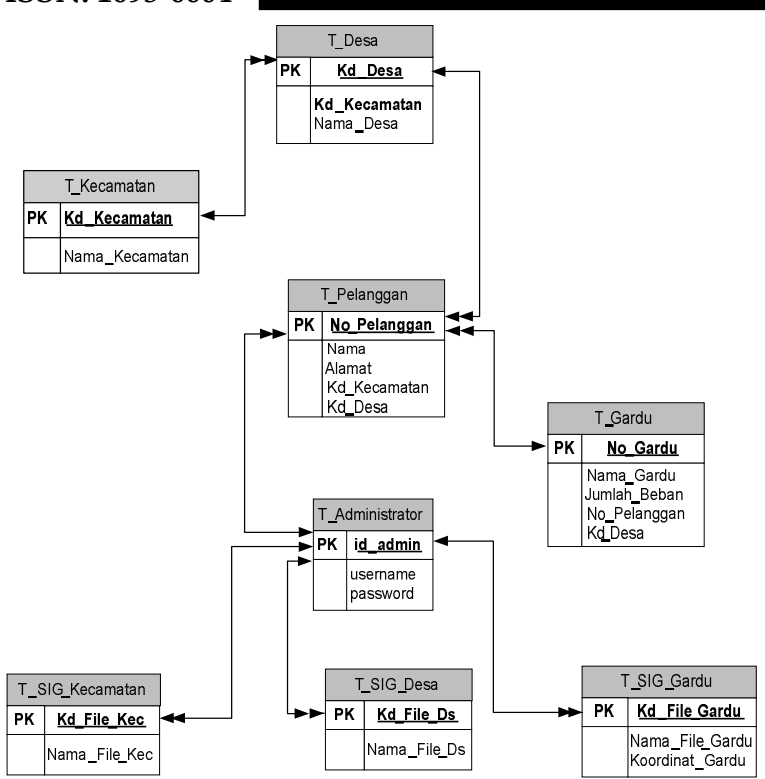

Gambar 3. Entity Relationship Diagram

Dari diagram tersebut maka maka masingmasing tabel dapat dijabarkan dalam masingmasing field, tipe data serta ukuran tipe.

\section{KESIMPULAN}

1. Sistem informasi Geografis Gardu Listrik dapat membantu dalam memudahkan penanganan gardu yang ada di PT. PLN (Persero) APJ Majalaya Baleendah Bandung.

2. Dengan bantuan sistem informasi geografis ini pengolahan gardu yang terdapat di PT. PLN (Persero) APJ Majalaya menjadi lebih tertata dan menghemat waktu dalam pencarian gardu.

3. Memudahkan dalam proses pencarian letak gardu dalam dokumen fisik.

4. Memudahkan dalam proses pencarian letak gardu yang telah disimpan dalam bentuk digital.

\section{REFERENSI}

[1] Jogiyanto HM, (1999), Analisis \& Desain Sistem Informasi Pendekatan Terstruktur Teori dan Praktek Aplikasi Bisnis Edisi 2, Andi, Yogyakarta.

[2] Jogiyanto HM, MBA, PH, (2000), Pengenalan Komputer, Andi Offset, Yogyakarta.
[3] Eddy Prahasta, (2007), Membangun Aplikasi Web-based GIS dengan MapServer, Informatika, Bandung.

[4] Eddy Prahasta, (2002), Konsep Dasar Sistem Informasi Geografis, Informatika, Bandung. 